\title{
JESYA
}

JURNAL EKONOMI \& EKONOMI SYARIAH

Jurnal Ekonomi \& Ekonomi Syariah Vol 4 No 1, Januari 2021

E-ISSN : 2599-3410|P-ISSN : 2614-3259

DOI : https://doi.org/10.36778/jesya.v4i1.237

\section{Pengaruh Sosial Ekonomi Nelayan terhadap Minat Belajar Anak di Masyarakat Bandar Kalifah}

\author{
Rakhmawati Purba \\ STIE Bina Karya \\ Rahmapurba2009@gmail.com
}

\begin{abstract}
Abstrak Penelitian ini bertujuan untuk menguji pengaruh sosial ekonomi petani terhadap minat belajar anak. Penelitian ini merupakan penelitian deskriptif kuantitatif. Variabel independen penelitian adalah sosial ekonomi petani yang terdiri dari latar belakang pendidikan orang tua, pendapatan dan pengeluaran keluarga dan kepemilikan kekayaan. Sedangkan variabel dependen penelitian adalah minat belajar anak. Penelitian dilakukan di masyarakat Bandar kalifah. Data yang digunakan adalah data primer dengan jumlah sampel sebanyak 51 responden. Metode analisis data dalam penelitian ini menggunakan metode analisis regresi linier berganda. Hasil penelitian menunjukkan bahwa pendapatan dan pengeluaran keluarga dan kepemilikan kekayaan berpengaruh signifikan terhadap minat belajar anak. Selanjutnya, penelitian ini tidak menemukan bukti bahwa latar belakang pendidikan orang tua memiliki pengaruh signifikan terhadap minat belajar anak.
\end{abstract}

Kata Kunci Latar Belakang Pendidikan, Pendapatan dan Pengeluaran, Minat Belajar

\section{PENDAHULUAN}

Pendidikan merupakan salah satu bentuk pembangunan Nasional untuk meningkatkan kecerdasan masyarakat, sehingga terwujud masyarakat yang cerdas, maju, dan sejahtera. Menurut Undang-Undang Republik Indonesia No. 20 Tahun 2003 Bab VI Pasal 6 tentang Sistem Pendidikan Nasional yaitu setiap warga Negara yang berusia tujuh sampai dengan lima belas tahun wajib mengikuti pendidikan dasar.

Menurut Siswoyo (2011), sesuatu yang ingin dicapai oleh kegiatan pendidikan adalah suatu yang logis bahwa pendidikan itu harus dimulai dengan tujuan yang diasumsikan sebagai nilai. Tanpa tujuan, maka dalam praktik pendidikan tidak ada artinya. Dalam pasal 3 UU Nomor 20 tahun 2003 tentang Sistem Pendidikan Nasional, tujuan pendidikan Nasional yaitu "untuk berkembangnya potensi peserta didik agar menjadi manusia yang beriman dan bertaqwa kepada Tuhan Yang Maha Esa, berakhlak mulia, sehat, berilmu, cakap, kreatif, mandiri, dan menjadi warga negara yang demokratis serta bertanggung jawab."

Dalam keseluruhan proses pendidikan yang diselenggarakan oleh lembaga pendidikan baik lembaga pendidikan formal, informal maupun non formal, belajar merupakan kegiatan yang paling pokok guna mencapai tujuan pendidikan. Belajar 
adalah suatu proses yang menimbulkan terjadinya suatu perubahan atau pembaharuan dalam tingkah laku atau kecakapan. Jadi, belajar bukanlah tingkah laku yang nampak, tetapi terutama adalah prosesnya yang terjadi secara internal didalam diri individu tersebut. Belajar tidak hanya mempelajari mata pelajaran, tetapi juga penyusunan, kebiasaan, persepsi, kesenangan atau minat, penyesuaian sosial dan cita-cita (Hamdani, 2011).

Menurut Fatimah (2010) "kelompok yang mempunyai status sosial ekonomi rendah, kurang menekankan pentingnya pencapaian pendidikan yang lebih tinggi". Kurangnya penekanan mengenai pentingnya pendidikan yang lebih tinggi, mempengaruhi motivasi belajar anak. Anak akan cenderung memiliki motivasi belajar rendah, karena semua kebutuhan untuk kepentingan belajar baik di sekolah maupun di rumah tidak terpenuhi oleh orang tuanya, sehingga anak menjadi tidak memiliki semangat dalam belajar.

Pendapatan orang tua memegang peranan penting dalam menunjang pendidikan anak. Pendapatan dapat diartikan sebagai hasil yang diterima seseorang karena orang itu bekerja dan hasilnya bisa berupa uang atau barang. Pendapatan orang tua adalah hasil yang diterima orang tua dari hasil bekerja, baik dari pekerjaan pokok maupun pekerjaan sampingan yang berupa uang atau barang yang dinilai dengan uang. Sedangkan pendapatan keluarga adalah semua hasil yang diterima seluruh anggota keluarga dari bekerja baik dari pekerjaan pokok maupun pekerjaan sampingan berupa uang atau barang yang dapat dinilai dengan uang.

Pengeluaran adalah pengeluaran konsumsi rumah tangga untuk semua barang atau jasa yang di peroleh secara pembelian baik tunai maupun kredit oleh rumah tangga tersebut, tetapi tidak untuk keperluan usaha maupun investasi. Oleh karena itu pengeluaran untuk tabungan, asuransi jiwa, kontribusi dana pensiunan, investasi dan pemberian kepada pihak lain tidak termasuk dalam konsumsi rumah tangga.

Selanjutnya, kekayaan sering diasosiasikan sebagai salah simbol harapan akan Pendidikan yang berkualitas. Keluarga yang memiliki kekayaan berlimpah cenderung memiliki Pendidikan yang lebih baik karena memiliki kemampuan dalam mengakses pendidikan yang berkualitas. Kekayaan dapat diartikan sebagai pemilikan barang-barang yang bersifat ekonomis atau yang memiliki nilai jual dan sebagai salah satu faktor yang melatar belakangi pelapisan sosial ekonomi dalam kehidupan bermasyarakat. Kekayaan keluarga dapat dilihat dari besar kecilnya rumah, sawah/kebun yang dimiliki, perhiasan yang dipakai, fasilitas dalam kehidupannya, dan juga harta yang tak terlihat seperti tabungan atau investasi modal.

Dari kondisi sosial ekonomi keluarga yang berbeda-beda, seperti tingkat pendidikan, kekayaan yang dimiliki, dan pemenuhan kebutuhan keluarga sehingga dalam penelitian ini, ingin diketahui apakah ada pengaruhnya kondisi sosial ekonomi orangtua terhadap minat belajar anak. Selain itu, sekolah sebagai salah satu pusat pendidikan berupaya membantu meningkatkan perkembangan baik perkembangan aspek spiritual, kognitif, dan juga psikomotorik siswa. Akan tetapi, minat belajar siswa banyak dipengaruhi oleh beberapa faktor baik dari dalam diri 
maupun dari luar diri siswa. Salah satu faktor yang akan diteliti adalah faktor dari luar siswa yaitu faktor kondisi sosial ekonomi keluarga.

\section{LANDASAN TEORI}

1. Kondisi Sosial Ekonomi

Kondisi sosial ekonomi merupakan suatu keadaan atau kedudukan yang diatur secara sosial dalam posisi tertentu dalam struktur masyarakat, pemberian posisi ini disertai pula seperangkat hak dan kewajiban yang hanya dipenuhi sipembawa statusnya, misalnya: pendapatan, pekerjaan, dan pendidikan, Soekanto (2010).

Santrock (2014) mengemukakan sosial ekonomi adalah pengelompokkan orangorang berdasarkan kesamaan karakteristik pekerjaan, pendidikan ekonomi. Kondisi sosial ekonomi dari tiap-tiap orang tua dalam keluarga berbeda satu sama lain. Hal ini ditentukan oleh keadaan dalam keluarga tersebut (misalnya: jumlah anggota keluarga, komunikasi yang terjalin dalam keluarga, perhatian dari orang tua terhadap anak, dan hubungan keluarga dengan masyarakat sekitar).

Terdapat beberapa faktor yang mempengaruhi kondisi sosial ekonomi seseorang. Faktor-faktor tersebut antara lain:

\section{Latar Belakang Pendidikan Orang Tua.}

Pendidikan orang tua disini adalah pendidikan formal, yaitu sampai pendidikan formal apa yang telah ditempuh oleh petani berupa SD, SMP, SMA, Perguruan Tinggi. Latar belakang pendidikan ini berpengaruh pada keberhasilan pendidikan anaknya, orang yang tingkat pendidikannya tinggi akan mempunyai wawasan yang jauh kedepan tentang pendidikan anaknya dibandingkan dengan yang berpendidikan rendah. Pendidikan orang tua juga berpengaruh pada gagasan dan kemampuan berfikir orang tua. Orang tua yang berpendidikan tinggi akan mempunyai gagasan atau pemikiran yang tinggi tentang pentingnya pendidikan bagi anaknya.

\section{Pendapatan dan Pengeluaran Keluarga}

Tingkat pendapatan merupakan indikator penting untuk mengetahui tingkat hidup rumah tangga. Umumnya pendapatan rumah tangga tidak berasal dari satu sumber, akan tetapi berasal dari dua atau lebih sumber pendapatan. Tingkat Pendapatan tersebut diduga dipengaruhi oleh pemenuhan kebutuhan dasar rumah tangga. Tingkat pendapatan yang rendah mengharuskan anggota rumah tangga untuk bekerja atau berusaha lebih giat untuk memenuhi kebutuhan hidupnya.

\section{Kepemilikan Kekayaan}

Kekayaan dapat diartikan sebagai pemilikan barang-barang yang bersifat ekonomis atau yang memiliki nilai jual dan sebagai salah satu faktor yang melatar belakangi pelapisan sosial ekonomi dalam kehidupan bermasyarakat. Kekayaan keluarga dapat dilihat dari besar kecilnya rumah, perhiasan yang dipakai, fasilitas dalam kehidupannya, dan juga harta yang tak terlihat seperti tabungan atau investasi modal. 


\section{Minat Belajar}

Menurut Slameto (2010) minat adalah suatu rasa lebih suka dan rasa ketertarikan pada satu hal atau aktivitas tanpa ada yang menyuruh. Minat pada dasarnya adalah penerimaan akan suatu hubungan antara diri sendiri dengan sesuatu diluar diri sendiri. Semakin kuat atau dekat hubungan tersebut, semakin besar minat.

Sedangkan menurut Syah (2010), minat bukanlah istilah yang popular dalam psikologi disebabkan ketergantungannya terhadap berbagai faktor internal lainnya seperti pemusatan perhatian, keingin tahuan, motivasi, dan kebutuhan. Secara sederhana, minat (interest) berarti kecenderungan dan kegairahan yang tinggi atau keinginan yang besar terhadap sesuatu.

Jadi minat adalah suatu dorongan dari dalam diri seseorang untuk melakukan sesuatu dengan rasa suka atau senang tanpa adanya paksaan dari pihak lain. Sedangkan minat belajar adalah dorongan yang berasal dari dalam dirinya sendiri untuk belajar dengan rasa suka atau senang tanpa adanya dorongan dari pihak lain.

Faktor yang mempengaruhi minat menurut Syah (2010) yaitu:

a. Faktor dari dalam

Faktor dari dalam atau faktor internal dipengaruhi oleh sifat bawaan yaitu keingin tahuan dari dalam diri seseorang yang terdiri dari perasaan tertarik, adanya perhatian, dan adanya aktivitas dari rasa senang itu sendiri, dan juga motivasi atau dorongan dari dalam diri siswa itu sendiri.

b. Faktor dari luar

Faktor dari luar terdiri dari aspek lingkungan sosial dan non sosial. Aspek lingkungan sosial terdiri dari kelompok, teman, masyarakat, dan sikap guru. Aspek non sosial terdiri dari rumah, peralatan, alam sekitar, dan bahan pelajaran.

c. Faktor Pendekatan belajar

Faktor pendekatan belajar adalah upaya siswa yang mencakup strategi dan metode yang digunakan siswa untuk mempelajari materi pelajaran. Faktor ini sering disebut dengan faktor emosional siswa yaitu ukuran intensitas seseorang dalam menaruh perhatiannya terhadap objek tertentu. Faktor pendekatan belajar juga mencakup proses dari belajar itu sendiri.

\section{Hipotesis Penelitian}

Berdasarkan latar belakang, rumusan masalah, dan kajian teori, maka dapat dirumuskan hipotesis penelitian sebagai berikut:

(1) Latar belakang pendidikan orang tua berpengaruh terhadap minat belajar anak di masyarakat Bandar Khalifah Kabupaten Batubara,

(2) Faktor pendapatan dan pengeluaran keluarga berpengaruh terhadap minat belajar anak di masyarakat Bandar Khalifah Kabupaten Batubara

(3) Faktor kepemilikan kekayaan berpengaruh terhadap minat belajar anak di masyarakat Bandar Khalifah Kabupaten Batubara, dan

(4) Latar Belakang pendidikan orang tua, pendapatan dan pengeluaran keluarga dan kepemilikan kekayaan secara simultan berpengaruh terhadap minat belajar anak. 


\section{METODOLOGI PENELITIAN \\ Populasi dan Sampel}

Menurut Sugiyono (2019), populasi adalah wilayah generalisasi, obyek/subyek yang mempunyai kualitas dan karakteristik tertentu yang ditetapkan oleh peneliti untuk dipelajari dan kemudian ditarik kesimpulannya. Populasi dalam penelitian ini adalah 101 orang masyarakat petani padi di masyarakat Bandar Khalifah. Jumlah sampel ditentukan dengan menggunakan rumus Slovin. Berdasarkan rumus Slovin, jumlah sampel yang dibutuhkan dalam penelitian ini sebanyak 51 responden.

\section{Jenis dan Sumber Data}

Penelitian ini merupakan penelitian deskriptif kuantitatif. Jenis data yang digunakan dalam penelitian ini adalah data kuantitatif yang bersumber dari data primer yaitu data yang diperoleh melalui penelitian langsung ke objek penelitian baik dengan kuesioner maupun wawancara langsung yang masih harus diolah peneliti.

\section{Teknik Analisis Data}

Penelitian ini menganalisis data dengan metode regresi linear berganda menggunakan bantuan software statistik SPSS 22. Model yang diuji adalah:

Dimana:

$$
\mathbf{Y}=\mathbf{a}+\mathbf{b}_{1} \mathbf{X}_{1}+\mathbf{b}_{2} \mathbf{X}_{2}+\mathbf{b}_{3} \mathbf{X}_{3}+\varepsilon
$$

$$
\begin{array}{ll}
\mathrm{Y} & =\text { Minat belajar anak } \\
\mathrm{X}_{1} & =\quad \text { Latar Belakang Pendidikan Orang Tua } \\
\mathrm{X}_{2} & =\quad \text { Pendapatan dan pengeluaran keluarga } \\
\mathrm{X}_{3} & =\text { Kepemilikan Kekayaan } \\
\alpha & =\text { Konstanta } \\
\beta_{1,2,3} & =\text { Koefisien regresi } \\
\mathrm{e} & =\text { standard error }
\end{array}
$$

\section{Uji Asumsi Klasik}

Uji asumsi klasik dalam penelitian ini mencakup uji normalitas, uji multikolinearitas, dan uji heteroskedastisitas. Uji normalitas menggunakan uji Kolmogorov-Smirnov dengan ketentuan, data berdistribusi normal apabila nilai Asymp. Sig. (2-tailed) lebih besar dari 0,05. Untuk menguji masalah multikolinearitas, penelitian ini menggunakan angka VIF (Variance Inflation Factor) sebagai tolak ukur ada tidaknya masalah multikolinearitas dalam model. Model dikatakan bebas dari masalah multikolinearitas apabila nilai VIF $<10$. Penelitian ini mendeteksi adanya heterokedastisitas dengan melihat grafik plot antara nilai prediksi variable terikat (ZPRED) dengan residualnya (SRESID).

\section{HASIL PENELITIAN Uji Asumsi Klasik Uji normalitas}

Hasil uji normalitas ditunjukkan dalam Tabel 1 berikut: 
Tabel 1. Hasil Uji Normalitas

One-Sample Kolmogorov-Smirnov Test

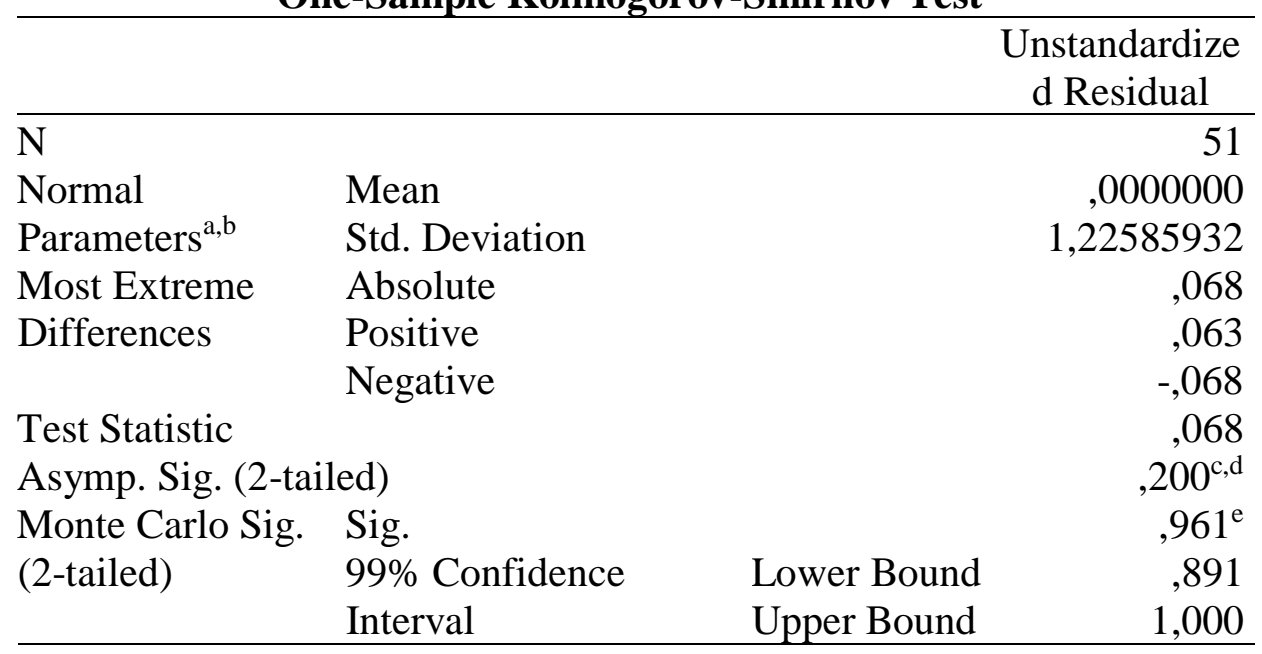

Berdasarkan Tabel 1, diketahui bahwa nilai signifikansi (Monte Carlo Sig. Lower Bound) seluruh variabel sebesar 0,891. Jika signifikansi lebih dari 0,05, maka nilai residual tersebut telah normal, sehingga dapat disimpulkan jika seluruh variabel berdistribusi normal.

\section{Uji multikolinearitas}

Uji multikolinieritas bertujuan untuk mengetahui apakah di dalam model regresi terdapat korelasi antar variabel independen. Hasil uji multikolinearitas dirangkum dalam Tabel 2 berikut: 
Tabel 2. Hasil Uji Multikolinearitas

\begin{tabular}{|c|c|c|}
\hline Variabel & VIF & Kesimpulan \\
\hline $\mathrm{X} 1$ & 1,003 & Bebas Multikolinearitas \\
\hline $\mathrm{X} 2$ & 1,076 & Bebas Multikolinearitas \\
\hline $\mathrm{X} 3$ & 1,080 & Bebas Multikolinearitas \\
\hline
\end{tabular}

Dari Tabel 2 di atas, diketahui bahwa nilai VIF $<10$. Hal ini menunjukkan bahwa model bebas dari masalah multikolinearitas.

\section{Uji heteroskedastisitas}

Uji heteroskedasitas bertujuan untuk menguji apakah dalam model regresi terjadi ketidaksamaan variance dari residual satu pengamatan ke pengamatan lain. Hasil uji heteroskedastisitas terlihat dalam Gambar 2 berikut:

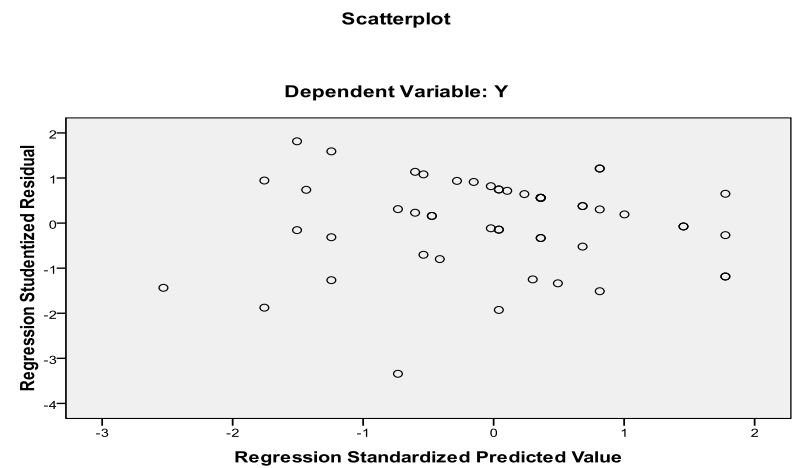

Gambar 2. Grafik Scatterplot

Berdasarkan Gambar 2 tersebut, dapat dilihat jika pola data menyebar sempurna, sebagian berada di atas titik nol dan sebagian lagi menyebar di bawah titik nol. Karena ini dapat disimpulkan tidak terdapat gejala heteroskedastisitas dalam model regresi.

\section{Pengujian Hipotesis}

\section{Uji koefisien determinasi (Adjusted $\boldsymbol{R}^{2}$ )}

Hasil uji koefisien determinasi dapat dilihat pada Tabel 3 berikut:

Tabel 3. Hasil Uji Koefisien Determinasi

\begin{tabular}{|c|c|c|c|c|c|c|c|}
\hline & & \multirow[b]{3}{*}{$\begin{array}{c}R \\
\text { Square }\end{array}$} & \multicolumn{2}{|c|}{ Model Summary $b$} & \multirow{2}{*}{\multicolumn{3}{|c|}{ Change Statistics }} \\
\hline \multirow[b]{2}{*}{ Model } & \multirow[b]{2}{*}{$\boldsymbol{R}$} & & & & & & \\
\hline & & & $\begin{array}{c}\text { Adjusted } R \\
\text { Square }\end{array}$ & $\begin{array}{c}\text { Std. Error of the } \\
\text { Estimate }\end{array}$ & $\begin{array}{c}\text { R Square } \\
\text { Change }\end{array}$ & $\begin{array}{c}F \\
\text { Change } \quad d f 1 \quad d f 2\end{array}$ & $\begin{array}{l}\text { Sig. } F \\
\text { Change }\end{array}$ \\
\hline 1 &, $843^{\mathrm{a}}$ &, 710 & ,692 & 1,26438 &, 710 & 38,399 &, 000 \\
\hline
\end{tabular}

Berdasarkan Tabel 3 dapat diketahui besarnya nilai adjusted $R$ square sebesar 0,692 atau $69,2 \%$. Hal ini menunjukkan jika Variabel X1, Variabel X2 dan Variabel X3 dapat 
menjelaskan Variabel Y sebesar 69,2\%, sisanya sebesar 30,8\% (100\% - 69,2\%) dijelaskan oleh variabel lain di luar model penelitian ini.

Uji statistik F

Hasil uji statistik F dapat dilihat dalam Tabel 4 berikut:

Tabel 4. Hasil Uji Statistik F

ANOVA $^{\mathrm{a}}$

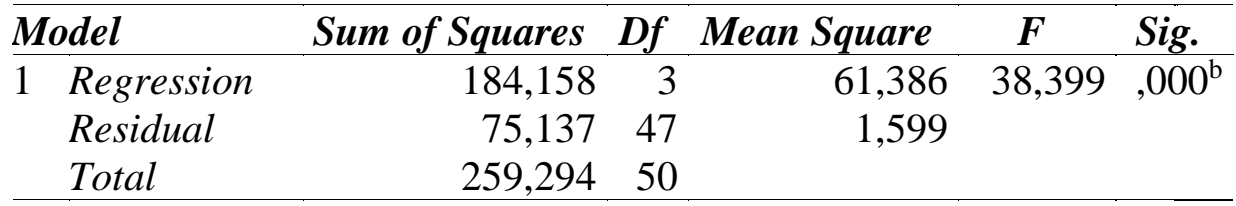

a. Dependent Variable: $\mathrm{Y}$

b. Predictors: (Constant), X3, X1, X2

Dari Tabel 4 diperoleh nilai $F_{\text {hitung }}$ sebesar 38,399 Dengan $\alpha=5 \%$, dk pembilang : $\mathrm{k}$, dk penyebut : n-k-1 $(5 \% ; 3 ; 47)$ diperoleh nilai $F_{\text {tabel }}$ sebesar 2,802. Dari uraian tersebut dapat diketahui bahwa $F_{\text {hitung }}(38,399)>F_{\text {tabel }} 2,802$, dan nilai signifikansi sebesar $0,000<0,05$ maka dapat disimpulkan hipotesis keempat diterima, artinya Variabel Latar Belakang Pendidikan Orang Tua, Pendapatan dan Pengeluaran, dan Kepemilikan Kekayaan berpengaruh secara serentak terhadap Minat Belajar Anak.

Uji T

\begin{tabular}{|c|c|c|c|c|}
\hline \multirow[b]{3}{*}{ Model } & \multicolumn{2}{|c|}{$\begin{array}{c}\text { Tabel 5. Hasil Uji t } \\
\text { Coefficients }^{a}\end{array}$} & \multirow[b]{2}{*}{$t$} & \multirow[b]{2}{*}{ Sig. } \\
\hline & \multicolumn{2}{|c|}{$\begin{array}{c}\text { Unstandardized } \\
\text { Coefficients }\end{array}$} & & \\
\hline & $B$ & Std. Error & & \\
\hline 1 (Constant) & 2,133 & 1,838 & 1,160 & 252 \\
\hline$X 1$ &,- 136 &, 146 &,- 935 & 354 \\
\hline$X 2$ & ,667 &, 132 & 5,045 &, 000 \\
\hline$X 3$ &, 672 &, 163 & 4,121 &, 000 \\
\hline
\end{tabular}

Persamaan regresi:

$Y=2,133-0,136 X_{1}+0,667 X_{2}+0,261 X_{3}$

Dari Tabel 5 diperoleh nilai thitung sebesar -0,935 Dengan $\alpha=5 \%$, $\mathrm{t}_{\text {tabel }}(5 \%$; $\mathrm{n}-\mathrm{k}=51-3)$ diperoleh nilai $t_{\text {tabel }}$ sebesar 2,011 Dari uraian tersebut dapat diketahui bahwa $t_{\text {hitung }}$ ($0,935)<t_{\text {tabel }}(2,011)$, demikian pula dengan nilai signifikansinya sebesar 0,354>0,05 maka dapat disimpulkan hipotesis pertama ditolak, artinya Variabel Latar Belakang Pendidikan Orang Tua (X1) tidak berpengaruh terhadap Variabel Minat Belajar Anak (Y).

Dari Tabel 5 diperoleh nilai thitung sebesar 5,045 Dengan $\alpha=5 \%$, $\mathrm{t}_{\text {tabel }}(5 \%$; $\mathrm{n}-\mathrm{k}=51-3)$ diperoleh nilai tabel sebesar 2,011. Dari uraian tersebut dapat diketahui bahwa thitung $(5,045)>$ tabel $(2,011)$, dan nilai signifikansinya sebesar $0,000<0,05$ maka dapat disimpulkan hipotesis kedua diterima, artinya Variabel X2 berpengaruh terhadap Variabel Y. 
Dari Tabel 5 diperoleh nilai thitung sebesar 4,121. Dengan $\alpha=5 \%, \mathrm{t}_{\text {tabel }}(5 \%$; $\mathrm{n}-\mathrm{k}=51-3)$ diperoleh nilai tabel sebesar 2,011. Dari uraian tersebut dapat diketahui bahwa thitung $(4,121)>t_{\text {tabel }}(2,011)$, dan nilai signifikansinya sebesar $0,000<0,05$ maka dapat disimpulkan hipotesis kedua diterima, artinya Variabel X3 berpengaruh terhadap Variabel Y

\section{KESIMPULAN DAN SARAN}

\section{Kesimpulan}

Berdasarkan hasil pengujian yang telah dilakukan, maka dapat ditarik beberapa kesimpulan sebagai berikut:

1. Latar belakang pendidikan orang tua tidak berpengaruh terhadap minat belajar anak.

2. Pendapatan dan pengeluaran keluarga berpengaruh positif dan signifikan terhadap minat belajar.

3. Kepemilikan kekayaan berpengaruh positif dan signifikan terhadap minat belajar anak.

4. Latar belakang pendidikan orang tua, pendapatan dan pengeluaran keluarga, dan kepemilikan kekayaan berpengaruh secara simultan terhadap minat belajar anak.

\section{Saran}

Berdasarkan beberapa kesimpulan diatas, maka saran yang dapat peneliti berikan antara lain sebagai berikut:

1. Berdasarkan kondisi sosial ekonomi masyarakat petani di Bandar Kalifah Kabupaten Batubara tersebut, maka diharapkan orang tua agar peduli terhadap kebutuhan pendidikan anak.

2. Cara meningkatkan minat belajar anak yang dapat dilakukan oleh orang tua yaitu dengan memberikan reward atau penghargaan setiap prestasi yang didapatkan anak. Karena anak akan lebih semangat dalam belajar untuk mendapatkan nilai yang baik agar diberi reward.

\section{DAFTAR PUSTAKA}

Dwi Siswoyo dkk (2018), Ilmu Pendidikan, Yogyakarta : UNY Press.

Fatimah, Enung (2010), Psikologi Perkembangan (Perkembangan Peserta Didik), Bandung : Pustaka Setia.

Hamdani (2017), Strategi Belajar Mengajar, Cetakan Keenam, Bandung : Pustaka Setia.

Santrock (2014), Kondisi Sosial Ekonomi, Jakarta : Graha Pustaka.

Slameto (2010), Belajar dan Faktor-Faktor Mempengaruhinya, Jakarta : Rineka Cipta.

Soerjono Soekanto (2010), Sosiologi Suatu Pengantar, Jakarta : Raja Grafindo Persada.

Sugiono (2019), Metode Penelitian Kuantitatif, Kualitatif dan R\&D, Cetakan ke-20, Bandung : Alfabeta. 
Jurnal Ekonomi \& Ekonomi Syariah Vol 3 No 1, Januari 2020

E-ISSN : 2599-3410 | P-ISSN : 4321-1234

DOI : https://doi.org/10.36778/jesya.v3i1.66

Syah Muhibbin (2010), Psikologi Pendidikan : Dengan Pendekatan Baru, Bandung : PT Remaja Rosdakarya.

Undang-Undang Repoblik Indonesia Nomor 20 Tahun 2003 Tentang Sistem Pendidikan Nasional. 